\title{
CORRELATION BETWEEN INITIAL BLOOD COUNT AND CLINICAL PARAMETERS IN CHILDREN WITH ACUTE LYMPHOBLASTIC LEUKEMIA
}

\author{
Milica Đorićc ${ }^{1}$, Nataša Benović ${ }^{1,}$ Jelena Lazić ${ }^{2}$ \\ ${ }^{1}$ Medicinski fakultet Univerziteta u Beogradu \\ ${ }^{2}$ Mentor, University Children's Hospital, Belgrade, Serbia
}

Sažetak

Uvod: ALL je najčešća neoplazma dečje dobi i čini trećinu svih pedijatrijskih maligniteta. Viši procenat preživljavanja i smanjena incidenca životno ugrožavajućih komplikacija su direktno uslovljeni ranim prepoznavanjem bolesti.

Cilj: Cilj studije je da prikaže i međusobno korelira inicijalne kliničke i laboratorijske parametre u dece sa ALL.

Materijal i metode: Retrospektivna studija je uključila 132 dece, dijagnostikovanih i lečenih po savremenim BFM protokolima. Inicijalna krvna slika je podrazumevala broj leukocita (Le), nivo hemoglobina (Hgb), broj trombocita (Tr) i procenat limfoblasta (LB) u perifernom razmazu. Od kliničkih parametara na prezentaciji su izdvojeni kao značajni: febrilnost, limfadenopatija, hepatomegalija i splenomegalija.

Rezultati: Broj Le se kretao od 1000-1050000/

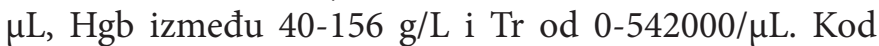
više od pola pacijenata uočen je poremećaj sve tri ćelijske loze, dok je krvna slika bila u granicama referentnih vrednosti kod dva deteta. Svega sedmoro dece je imalo uredan klinički nalaz. Kod većine pacijenata su febrilnost, limfadenopatija, hepatomegalija i splenomegalija bili prisutni i korelirali su sa Le $>20000 / \mu \mathrm{L}$, $\mathrm{Hgb}<120 \mathrm{~g} / \mathrm{L} \mathrm{i} \mathrm{Tr}<50000 / \mu \mathrm{L}$.

Zaključak: Varijacije u kliničkoj slici i laboratorijskim parametrima ukazuju na raznolikost prezentacije akutne limfoblastne leukemije (ALL) u pedijatrijskoj populaciji. Većina pacijenata ima ili kliničku sliku ili poremećaj parametara krvne slike koji pobuđuju sumnju na ALL, ali je izazov prepoznati pacijente sa odsustvom kliničkih simptoma i laboratorijskim nalazima unutar referentnih granica za uzrast. Po našim saznanjima, ovo je prva studija koja ispituje inicijalne kliničke i laboratorijske parametre u dece sa ALL u Srbiji. Želimo da ukažemo na značaj ranog prepoznavanja simptoma i znaka ove bolesti.

Ključne reči: akutna limfoblastna leukemija, deca, klinički nalaz, laboratorijski parametri
Abstract

Introduction: ALL is the most common malignancy in children, accounting for one third of all pediatric cancer patients. It is of crucial importance to recognise the disease on time to ensure good outcome and prevent initial complications.

Aim: Study aim was to correlate blood count and clinical parameters on diagnosis in children with ALL.

Material and Methods: Retrospective study included 132 children, diagnosed and treated according to current BFM protocols. Initial blood analysis included leukocyte count (WBC), hemoglobin level (Hgb), platelet count (Plt) and percent of lymphoblasts in peripheral smear. Initial clinical parameters included fever, lymphadenopathy, hepatomegaly and splenomegaly.

Results: WBC ranged from $1000-1050000 / \mu \mathrm{L}$, Hgb between $40-156 \mathrm{~g} / \mathrm{L}$ and Plt from $0-542000 / \mu \mathrm{L}$. More than half of the children had all three lineages affected, while $\mathrm{CBC}$ within reference range was found in two patients. Only seven children had normal clinical findings. In majority of patients fever, lymphadenopathy, hepatomegaly and splenomegaly was present and strongly correlated with WBC $>20000 / \mu \mathrm{L}, \mathrm{Hgb}<120 \mathrm{~g} / \mathrm{L}$ and Plt $<50000 / \mu \mathrm{L}$.

Conclusion: Affection of initial laboratory parameters and variety of clinical presentations demonstrate the diverse onset of acute lymphoblastic leukemia (ALL). Majority of patients have either clinical features or complete blood count values raising suspicion of ALL, but we point out to the patients with findings within the reference range. To the best of our knowledge we are the first to present data on initial CBC and clinical findings in children with ALL in Serbia. We stress the importance of early recognition of signs and symptoms in children with ALL.

Keywords: acute lymphoblastic leukemia, children, clinical findings, laboratory parameters 


\section{Introduction}

Cancer in children accounts for $1 \%$ of all patients with malignant diseases. Acute lymphoblastic leukemia (ALL) is the most frequent malignancy in children, representing approximately $35 \%$ of all pediatric cancer patients [1]. The peak incidence of ALL is among preschool children. The gender distribution is almost equal, with slight predominance of females among infants and males in adolescent age.

ALL is clonal malignant disease of immature precursors of lymphoid lineage, named lymphoblasts. Extensive growth of lymphoblasts suppresses the normal cell production in bone marrow causing various clinical findings such as pallor, fatigue, bleeding, fever, infection [2].

Improved diagnostic tools and application of contemporary treatment protocols, based on precise risk stratification, ensure survival rate above 85\% [3]. Recognizing the rare disease, as leukemia in children, is of major importance for early diagnosis and start of treatment. Suspicion on leukemia in previously healthy child is primarily based on clinical findings and complete blood count (CBC). Detailed anamnesis, physical examination and blood count are in most cases sufficient for differential diagnosis in aim to rule out other medical conditions.

Fever is one of the most common symptoms in childhood and it is hard to distinguish it as a sign of leukemia [4]. Localized lymphadenopathy, most commonly cervical, can be found in almost half of healthy children as non-significant finding on routine examination. Unilateral, generalized or persistently enlarged lymph nodes increase the attention to lymphoproliferative disorders, including ALL $[2,5]$. Finding of hepatomegaly, splenomegaly or both, in child without anamnestic data of congenital or hereditary disorders, are usually first obvious signs that refer to more complex diagnostic consideration [2]. Presence of one or more of these symptoms and signs should never be ignored and if carefully evaluated can greatly contribute to prompt diagnosis of leukemia.

When ALL is suspected due to anamnestic and clinical data, CBC and peripheral smear (PS) are the first laboratory tools to be obtained. Changes in hematological parameters in $\mathrm{CBC}$ can be various, affecting one, two or all three cell lineages, resulting as leucopenia or leukocytosis with neutropenia, anemia, and thrombocytopenia [2]. The majority of the viral infection can result in moderate leucopenia, but usually other cell lineages are not affected [6]. Iron deficient anemia is one of the most common diseases worldwide [7], and rarely anemia is the only finding in child with ALL. The severe thrombocytopenia can be prominent sign in pediatric patients with ALL, but is also diagnosed as isolated disorder.
ALL is a rare disease, with incidence of 80 per million between 2 nd and 3rd year of life and 20 per million between 8 th and 10th year of life [8] and for pediatritians in primary care centers is not easy to suspect the diagnosis when assessing more common health problems of children.

Study aim was to correlate CBC and PS with clinical findings (fever, lymphadenopathy, hepatomegaly and splenomegaly) on diagnosis in children with ALL.

\section{Material and methods}

Patients

Retrospective cohort study included 132 consecutive children, diagnosed between December 2002 and December 2012 at the Department for Hematology and Oncology in University's Children Hospital in Belgrade, Serbia. All study patients were consecutively diagnosed and treated according to current BFM protocols. Anamnestic data and data on clinical findings were obtained from hospital medical charts. CBC was performed uniformly in all children at diagnosis, using automatic blood-cell analyzer, in addition to peripheral blood smear.

Clinical findings included: fever, lymphadenopathy, hepatomegaly and splenomegaly. Each initial laboratory parameter was correlated with every clinical finding. For the purpose of analysis initial laboratory parameters were divided into several groups for each cell lineage. White blood cell count (WBC): < 5000/ $\mu \mathrm{L}, 5-20000 /$ $\mu \mathrm{L}, 20-50000 / \mu \mathrm{L}, 50-100000 / \mu \mathrm{L}$ and $>100000 / \mu \mathrm{L}$. Initial hemoglobin level $(\mathrm{Hgb}):<50 \mathrm{~g} / \mathrm{L}, 50-100 \mathrm{~g} / \mathrm{L}, 100$

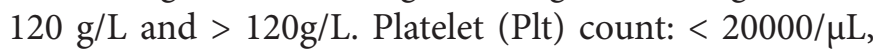
$20-50000 / \mu \mathrm{L}, 50-150000 / \mu \mathrm{L}$ and $>150000 / \mu \mathrm{L}$. Any percentage of lymphoblasts $>5 \%$ in PS was considered to be pathological.

\section{Statistical analysis}

Descriptive statistics was used to illustrate the age range, sex distribution, values of initial $\mathrm{CBC}$ and presence of clinical findings. Hi square test and Fisher exact probability test were both used, in a form of a contingency table for statistical analysis of correlation between laboratory and clinical findings on set.

\section{Results}

\section{Study patients}

Study group enrolled 132 patients with de novo diagnosed ALL, age ranged from 11 months to 17.6 years, median 5.5 years. Gender distribution revealed aslight 
predominance of males in $57.6 \%$ (76/132), versus $42.4 \%$ of female patients $(66 / 132)$.

\section{Initial blood count}

Leukocyte count on diagnosis ranged from 1000/ $\mu \mathrm{L}$ to $1050000 / \mu \mathrm{L}$, median $13000 / \mu \mathrm{L}$. Initial $\mathrm{WBC}<5000 /$ $\mu \mathrm{L}$ was seen in one quarter of patients (33/132), in approximately one third (31.8\%) ranged from 5000-20000/ $\mu \mathrm{L}(42 / 132)$, in $22 \%(29 / 132)$ between $20000-50000 /$ $\mu \mathrm{L}, 50000-100000 / \mu \mathrm{L}$ in $13.6 \%(18 / 132)$, while $\mathrm{WBC}$ $>100000 / \mu \mathrm{L}$ was detected in $7.6 \%(10 / 132)$ of children. Hemoglobin levels at diagnosis ranged between $40 \mathrm{~g} / \mathrm{L}$ and $156 \mathrm{~g} / \mathrm{L}$, with median level of $89 \mathrm{~g} / \mathrm{L}$. On admission $3.8 \%$ of patients $(5 / 132)$ had $\mathrm{Hgb}$ values $<50 \mathrm{~g} / \mathrm{L}$, in $59.1 \%$ of children (78/132) 50-100 g/L, levels between 100-120 $\mathrm{g} / \mathrm{L}$ were seen in $18.9 \%(25 / 132)$ and $18.2 \%(24 / 132)$ had reference values of $\mathrm{Hgb}$ for age $(>120 \mathrm{~g} / \mathrm{L})$. Platelet count ranged from $0 / \mu \mathrm{L}$ to $542000 / \mu \mathrm{L}$, with median count of $52000 / \mu \mathrm{L}$. In $16.7 \%$ of children (22/132) Plt count were found to be $<20000 / \mu \mathrm{L}$, in $28 \%(37 / 132)$ ranged from $20000-50000 / \mu \mathrm{L}$, values between $50000-150000 / \mu \mathrm{L}$ were detected in $34.8 \%$ of patients $(46 / 132)$, while in the rest of study group $(20.5 \%-27 / 132)$ Plt count was found to be within reference values $(>150000 / \mu \mathrm{L})$.

In $82.6 \%$ of children (109/132), presence of lymphoblasts in PS was notified, of whom $90.8 \%$ had $>5 \%$, which is considered to be pathological finding. Distribution of blood count parameters within different groups is presented in Table 1.

One blood cell lineage was affected in $11.4 \%$ $(15 / 132)$ of patients, two in $36.4 \%$ (48/132) while all three were pathological in more than half of children $-50.8 \%$ (67/132). CBC within normal range was found in 1.5\% $(2 / 132)$ of study patients. Affection of blood cell lines is presented in Graph 1.

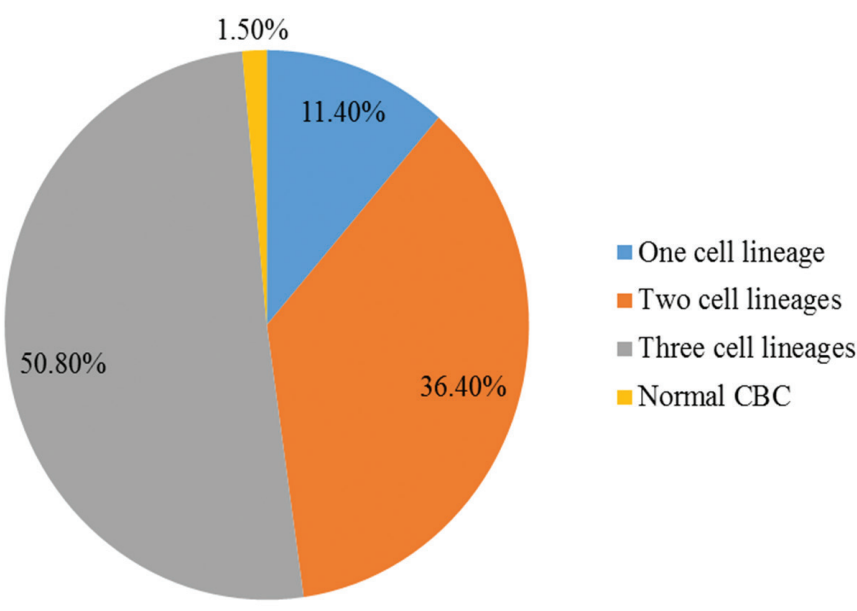

Graph 1. Affection of blood cell lineages in peripheral complete blood count in children with ALL

On diagnosis, 5.3\% (7/132) of patients had none of the observed clinical parameters (fever, lymphadenopathy, hepatomegaly, splenomegaly).

At presentation, fever was found in $62.9 \%$ (83/132), lymphadenopathy in $63.6 \%$ (84/132), hepatomegaly in $45.5 \%(60 / 132)$ and splenomegaly in $55.3 \%(73 / 132)$ of children. Frequency of investigated clinical parameters is shown in Graph 2.

Considering lymphadenopathy as clinical finding, the most frequent finding was generalized lymphadenopathy (cervical plus other site) in $29.5 \%$ of children (39/132), followed by cervical in $21.9 \%$ (29/132), while only axillar or only inguinal were seen, each, in one patient $(0.8 \%)$.

Each of our patients had either pathological finding in $\mathrm{CBC}$ or at least one clinical finding.

Table 1. Distribution of patients according to laboratory parameters

\begin{tabular}{|c|c|c|c|c|c|}
\hline WBC & $<5000 / \mu \mathrm{L}$ & $5-20000 / \mu \mathrm{L}$ & $20-50000 / \mu \mathrm{L}$ & $50-100000 / \mu \mathrm{L}$ & $>100000 / \mu \mathrm{L}$ \\
\hline$\%$ of pts & $25 \%$ & $31.80 \%$ & $22 \%$ & $13.6 \%$ & $7.6 \%$ \\
\hline
\end{tabular}

\begin{tabular}{|c|c|c|c|c|}
\hline $\mathrm{Hgb}$ & $<50 \mathrm{~g} / \mathrm{L}$ & $50-100 \mathrm{~g} / \mathrm{L}$ & $100-120 \mathrm{~g} / \mathrm{L}$ & $>120 \mathrm{~g} / \mathrm{L}$ \\
\hline$\%$ of pts & $37.1 \%$ & $25.8 \%$ & $18.9 \%$ & $18.2 \%$ \\
\hline
\end{tabular}

\begin{tabular}{|c|c|c|c|c|}
\hline Plt & $<20000 / \mu \mathrm{L}$ & $20-50000 / \mu \mathrm{L}$ & $50-150000 / \mu \mathrm{L}$ & $>150000 / \mu \mathrm{L}$ \\
\hline$\%$ of pts & $16.7 \%$ & $28 \%$ & $34.8 \%$ & $20.5 \%$ \\
\hline
\end{tabular}

\begin{tabular}{|c|c|c|c|}
\hline Blasts & $>5 \%$ & $<5 \%$ & Not present \\
\hline$\%$ of pts & $75 \%$ & $7.6 \%$ & $17.4 \%$ \\
\hline
\end{tabular}




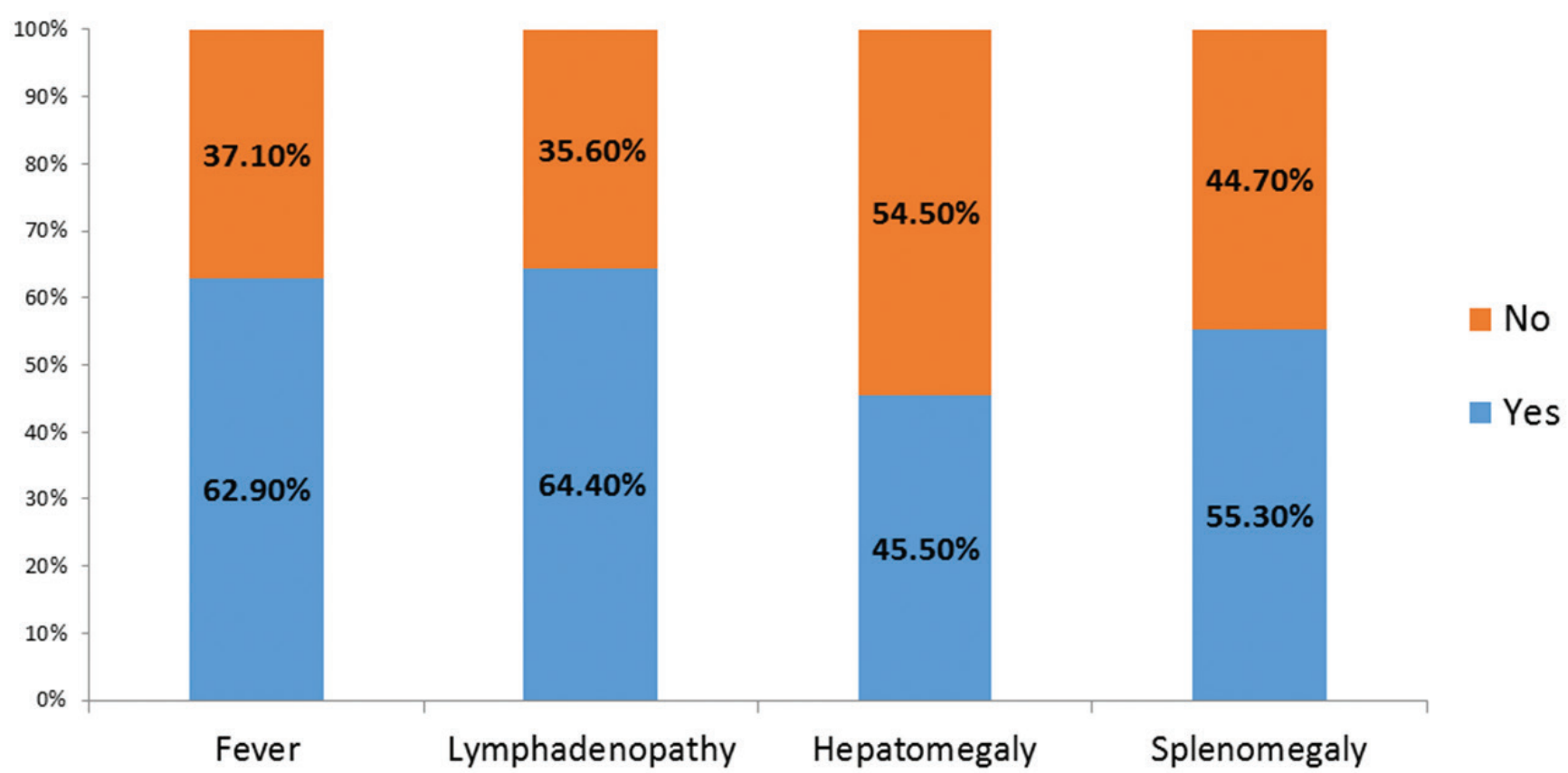

Graph 2. Frequency of investigated clinical parameter

\section{Correlation of initial WBC and clinical parameters}

Fever was found to be present more often in children with leukocyte count $\leq 5000 / \mu \mathrm{L}$ or $>20000 / \mu \mathrm{L}$ compared to those in whom WBC count was within reference values $(p=0.04)$.

In children with initial $\mathrm{WBC}>20000 / \mu \mathrm{L}$ lymphadenopathy was more probable on diagnosis $(\mathrm{p}=0.007)$.

Hepatomegaly was statistically more likely to be found in patients with $\mathrm{WBC}>20000 / \mu \mathrm{L}(\mathrm{p}=0.004)$. When comparing statistical significance in group of children with higher values of initial WBC count, we can notify that $\mathrm{p}$ value continues to grow but stays below 0.05 .

The highest statistical significance for splenomegaly was found in group of children with initial WBC $>20000 / \mu \mathrm{L}(\mathrm{p}=0.0008)$, but is also associated with higher count of WBC.

\section{Correlation of initial Hgb values and clinical parameters}

Fever was more common in patients with $\mathrm{Hgb}<120 \mathrm{~g} / \mathrm{L}(\mathrm{p}=0.004)$ than in those who had reference values of $\mathrm{Hgb}$.

Presence of lymphadenopathy and hepatomegaly did not reveal any statistical significance, when correlated with different values of initial $\mathrm{Hgb}$.

In contrast to lymphadenopathy and hepatomegaly, initial $\mathrm{Hgb}<120 \mathrm{~g} / \mathrm{L}$ was associated with splenomegaly, with statistical significance of $\mathrm{p}=0.017$.

\section{Correlation of initial Plt count and clinical} parameters

Fever was significantly more often present in children with Plt $<150000 / \mu \mathrm{L}$ ( $\mathrm{p}=0.008)$, while lymphadenopathy showed no correlation with initial Plt count.

Strong correlation with initial Plt count and both, hepatomegaly and splenomegaly, was found. Chance of liver or spleen enlargement is higher in children with thrombocytopenia $(\mathrm{p}=0.002$ and $\mathrm{p}=0.048)$. Initial Plt count of $<50000 / \mu \mathrm{L}$ showed the strongest statistical significance for both, hepatomegaly and splenomegaly $(\mathrm{p}=0.001$ and $\mathrm{p}<0.0001)$.

Correlation of initial presence of lymphoblasts in peripheral smear and clinical parameters

Initial presence of lymphoblasts in peripheral smear showed no correlation with any of the observed clinical parameters.

\section{Discussion}

\section{Study patients}

Sex and age distribution in our study group is similar to literature data [9]. The slight predominance of males and median age of pre-school children are already well established epidemiological fact in pediatric patients with ALL. 


\section{Initial blood count}

The cut off values of blood parameters were chosen based on their association with different medical conditions.

In our study group minimal initial $\mathrm{WBC}$ count was $1000 / \mu \mathrm{L}$ and maximal $1050000 / \mu \mathrm{L}$ - in both cases it is not difficult to suspect blood disorder, but median leukocyte count was $13000 / \mu \mathrm{L}$, which is not an alarming sign. One quarter of patients had mild leukopenia (WBC < 5000/ $\mu \mathrm{L}$ ), which is most commonly associated with viral infections, but in these benign conditions other cell lineages are usually not affected [6]. WBC between $5-20000 / \mu \mathrm{L}$, which can be considered to be within reference range for age, or associated with mild infections, was found in one third of children. In about one fifth of patients WBC was between 20-50000/ $\mu \mathrm{L}$, which can be indicative for serious infections. $\mathrm{WBC}>50000 / \mu \mathrm{L}$ directly raise suspicion towards blood malignancy and was seen in more than $10 \%$ of children [2]. Hyperleukocytosis (WBC > 100000/ $\mu \mathrm{L}$ ) was detected in less than $10 \%$ of patients and is associated with severe complications of disease at diagnosis $[10,11]$.

The minimal detected hemoglobin level in our study group was $40 \mathrm{~g} / \mathrm{L}$ and very few of the patients $(5 / 132)$ presented with severe anemia $(\mathrm{Hgb}<50 \mathrm{~g} / \mathrm{L})$, which is indicative for severe blood disorder. The maximal Hgb level at diagnosis was $156 \mathrm{~g} / \mathrm{L}$, and on admission one fifth of children had $\mathrm{Hgb}>120 \mathrm{~g} / \mathrm{L}$, which is considered to be within reference range for every age. Mild anemia with $\mathrm{Hgb}$ levels of $100-120 \mathrm{~g} / \mathrm{L}$ was detected in nearly $20 \%$ of patients and if we add previous group of children with reference $\mathrm{Hgb}$ values, they represent almost $40 \%$ of patients in whom diagnosis can be missed if relying only on this blood parameter. The majority of patients (59.1\%) had $\mathrm{Hgb}$ level between 50 and $100 \mathrm{~g} / \mathrm{L}$, with median level in our study group of $89 \mathrm{~g} / \mathrm{L}$, which in any case requires further testing [12].

Minimal detected Plt count on set was $0 / \mu \mathrm{L}$ and only in minority of children (16.7\%) Plt count below $20000 / \mu \mathrm{L}$ was detected, that correlates with spontaneous bleeding and can be easily recognised by clinical examination. In almost one third of patients Plt ranged from 20000 to $50000 / \mu \mathrm{L}$, the count that is associated with less prominent, but still recognizable hemorrhagic symptoms in an active child. Plt count between 50000-150000/ $\mu \mathrm{L}$ was found in $34.8 \%$ of patients and along with those who had Plt count within reference range (20.5\%) represent more than half of study group which does not have clinical signs of thrombocytopenia and makes diagnosis harder to obtain [13].

Despite wide WBC range at diagnosis, from $1000 / \mu \mathrm{L}$ to $1050000 / \mu \mathrm{L}$, in $82.6 \%$ of children, presence of lymphoblasts in PS was notified. Out of 109, 10 chil- dren were detected with $<5 \%$ of lymphoblasts. It takes an experienced and skilful laboratory technician and/or medical doctor to recognise possible immature and malignantly altered lymphocytes in aim to suspect the diagnosis of leukemia.

The most common finding was affection of all three cell lineages, in more than half of study patients, which facilitates the initial diagnosis of ALL. But, in two patients $\mathrm{CBC}$ was within reference range for age $(1.5 \%)$ and that fact raises the importance of anamnestic data and careful clinical examination.

\section{Initial clinical parameters}

Only few of the patients (7/132) had none of the observed clinical parameters, and as expected, fever and generalized lymphadenopathy were the most common, each accounting for more than $60 \%$ of patients. Fever is the prominent symptom of many benign conditions in early childhood in otherwise healthy children. In lack of clinical or laboratory signs of infection, fever should be carefully monitored [14]. Localized lymphadenopathy, especially cervical, can be found in around $45 \%$ of healthy children on regular doctor's appointment [5]. But we point out that generalized lymphadenopathy should be investigated if not already correlated to condition other than malignant. Supraclavicular lymphadenopathy is very indicative of malignant disease. Hepatomegaly and splenomegaly should be seriously evaluated, but are not exclusively associated with cancer [2].

\section{Correlation of initial laboratory and clinical parameters}

Fever was more common in patients who had WBC $<5000 / \mu \mathrm{L}$ and those who had Le count $>20000 / \mu \mathrm{L}$. Due to bone marrow infiltration by lymphocytes, neutropenia is present in patients with ALL, despite the WBC count, making children more prone to infections [15].

Strong association with $\mathrm{WBC}>20000 / \mu \mathrm{L}$ and lymphadenopathy, hepatomegaly and splenomegaly was seen, which is expected finding and can be explained by proliferation of leukemic cells and is considered as malignant infiltration [2].

Affection of red blood cells leading to decrease of Hgb level $(<120 \mathrm{~g} / \mathrm{L})$ makes fever and splenomegaly more common in children with ALL.

Fever, hepatomegaly and splenomegaly were associated with decreased Plt count. As the Plt count is dropping, the probability of liver or spleen enlargement is raising.

To the best of our knowledge we are the first to present data on initial CBC and clinical findings in children with ALL in Serbia. Several authors published data 
on local population, also pointing out that majority of children present with similar laboratory results and clinical features.

Malaysian study, even though difficult to compare due to the different cut off values used, showed similar incidence of normal or slightly low Hgb levels and Plt count and $\mathrm{WBC}>50000 / \mu \mathrm{L}$. Clinical findings were different, with higher frequency of hepatomegaly and splenomegaly in their study group [16].

Study conducted in France showed similar values of WBC, Hgb and Plt in comparison to our group [17].

Pakistani study showed that lymphadenopathy, hepatomegaly and splenomegaly were also significant clinical findings on diagnosis of ALL, but their patients had these features more often than children in our group. Anemia was also slightly more often in their patients and Plt count $<20000 / \mu \mathrm{L}$ was twice as often in Pakistani children than in Serbian patients [18].

Another study, conducted in India, showed that lymphadenopathy was not as often seen in their patient population when compared to ours, however fever, hepatomegaly and splenomegaly were much more often in Indian children [19].

\section{Conclusion}

In our study group of 132 consecutive patients with ALL, sex and age distribution matched the literature data.

Lymphadenopathy (especially generalized) was the most common clinical finding (63.6\%), followed by fever (62.9\%), splenomegaly (55.3\%) and hepatomegaly (45.5\%).

Majority of patients were diagnosed with initial WBC count ranging from 5000 to $20000 / \mu \mathrm{L}$. Fever is more often present in children with leukocyte count $\leq 5000 / \mu \mathrm{L}$ or $>20000 / \mu \mathrm{L}$, while lymphadenopathy, hepatomegaly and splenomegaly were more frequent in patients with WBC above $20000 / \mu \mathrm{L}$.

More than half of study group was diagnosed with $\mathrm{Hgb}$ values from 50 to $100 \mathrm{~g} / \mathrm{L}$. Children with mild or severe anemia showed to be more prone to fever and splenomegaly.

Plt count between $50000-150000 / \mu \mathrm{L}$ was detected in more than third of children, in whom fever, hepatomegaly and splenomegaly were present significantly more often.

Presence of lymphoblasts did not reveal any statistical significance when compared to investigated automated CBC and clinical parameters.

Special consideration is required for minority of children with laboratory parameters within reference range for age or absence of any clinical finding that associate with onset of ALL.
We are presenting data on initial $\mathrm{CBC}$ and clinical findings in children with ALL in Serbia aiming to help primary care pediatricians to make a timely diagnosis.

\section{References}

1. Ward, E. DeSantis, C., Robbins, A., Kohler, B. \& Jemal, A. Childhood and adolescent cancer statistics, CA Cancer J Clin, 2014; 64, 83-103.

2. Hastings, C. A., Torkildson, J. C. \& Agrawal, A. K. Evaluation of the Child with a Suspected Malignancy. In: Hastings, C. A., Torkildson, J. C. \& Agrawal, A. K. Handbook of Pediatric Hematology and Oncology: Children's Hospital \& Research Center Oakland. John Wiley \& Sons, Ltd; 2012; p.122-132.

3. Stary, J., Zimmermann, M., Campbell, M., Castillo, L., Dibar, E., Donska, S., et all. Intensive chemotherapy for childhood acute lymphoblastic leukemia: results of the randomized intercontinental trial ALL IC-BFM 2002. J Clin Oncol, 2014.; 32, 174-84.

4. Marshall, G. S. Prolonged and recurrent fevers in children. J Infect, 68 Suppl 1, 2014.;S83-93.

5. Locke, R., Comfort, R. \& Kubba, H. When does an enlarged cervical lymph node in a child need excision? A systematic review. Int J Pediatr Otorhinolaryngol, 2014; 78, 393-401.

6. Hoffbrand, A. V., Moss, P. A. H. \& Pettit, J. E. Essential haematology, Malden, Mass.; Oxford, Blackwell Pub. 2006.

7. Iron-deficiency anemia: reexamining the nature and magnitude of the public health problem, American Society for Nutritional Sciences, Bethesda, MD, USA. 2001.

8. Gurney J, Bondy M. Epidemiology of childhood cancer. In: Principles and practices of pediatric oncology, 5th Ed, Pizzo P, Poplack D. Lippincott Williams and Wilkins, Phil-adelphia 2006; p.1-13.

9. Bhatia S, Robinson LL: Epidemiology of leukemia in childhood. Nathan and Oski's Hematology of infancy and childhood. Nathan DG, Orkin SH, Ginsburg D, Look AT. Saunders 2003; Vol 2. p:1081-1100

10.Vaitkevičienè, G., Forestier, E., Hellebostad, M., Heyman, M., Jonsson, O. G., Lähteenmäki, P. M., Rosthoej, S., Söderhäll, S., Schmiegelow, K. \& (NOPHO), N. S. o. P. H. a. O. 2011. High white blood cell count at diagnosis of childhood acute lymphoblastic leukaemia: biological background and prognostic impact. Results from the NOPHO ALL-92 and ALL-2000 studies. Eur J Haematol, 86, 38-46.

11.Haase, R., Merkel, N., Diwan, O., Elsner, K. \& Kramm, C. M. Leukapheresis and exchange transfusion in children with acute leukemia and hyperleukocytosis. A single center experience. Klin Padiatr, 2009; 221, 374-8.

12.Hastings, C. A., Torkildson, J. C. \& Agrawal, A. K. Approach to the Anemic Child. In: Hastings, C. A., Torkildson, J. C. \& Agrawal, A. K. Handbook of Pediatric Hematology and Oncology: Children's Hospital \& Research Center Oakland. John Wiley \& Sons, Ltd; 2012; p.1-9.

13.Mangino J. Platelet Disorders. In: Florin, T. A., Ludwig, S. \& Netter, F. H. (eds.). Netter's Pediatrics. Philadelphia; Elsevier Saunders. 2011; p321-325. 
14.Kanabar, D. 2014. A practical approach to the treatment of low-risk childhood fever. Drugs R D, 14, 45-55.

15.O'Connor, D., Bate, J., Wade, R., Clack, R., Dhir, S., Hough, R. et all. 2014. Infection-related mortality in children with acute lymphoblastic leukemia: an analysis of infectious deaths on UKALL2003;Blood, 124, 1056-61.

16.Ng, S. M., Lin, H. P., Ariffin, W. A., Zainab, A. K., Lam, S. K. \& Chan, L. L. Age, sex, haemoglobin level, and white cell count at diagnosis are important prognostic factors in children with acute lymphoblastic leukemia treated with BFM-type protocol. J Trop Pediatr, 2000;46, 338-43.

17.Donadieu, J., Auclerc, M. F., Baruchel, A., Perel, Y., Bordigoni, P., Landman-Parker, J. et all. Prognostic study of continuous variables (white blood cell count, peripheral blast cell count, haemoglobin level, platelet count and age) in childhood acute lymphoblastic leukaemia. Analysis Of a population of 1545 children treated by the French Acute Lymphoblastic Leukaemia Group (FRALLE). Br J Cancer, 2000; 83, 1617-22.

18.Yasmeen, N. \& Ashraf, S. Childhood acute lymphoblastic leukaemia; epidemiology and clinicopathological features. J Pak Med Assoc,2009; 59, 150-3.

19.Biswas, S., Chakrabarti, S., Chakraborty, J., Paul, P. C., Konar, A. \& Das, S. Childhood acute leukemia in West Bengal, India with an emphasis on uncommon clinical features. Asian Pac J Cancer Prev, 2009;10, 903-6. 